УДК 615.1:355

DOI https://doi.org/10.11603/2312-0967.2021.3.12389

\title{
ОСВІТНЬО-НАУКОВІ АСПЕКТИ РОЗВИТКУ ПАЛІАТИВНОЇ ДОПОМОГИ В УКРАЇНІ
}

\author{
А. А. Котвіцька, І. В. Кубарєва, М. С. Бекетова \\ Національний фрармацевтичний університет мОз України \\ socpharm@nuph.edu.ua
}

ІНФОРМАЦІЯ

Надійшла до редакції / Received: 10.08.2021

Після доопрацювання / Revised: 07.09.2021

Прийнято до друку / Accepted: 08.09.2021

\section{Ключові слова:}

фрармацевтичні працівники; фрармацевтична освіта; паліативна допомога.
АНОТАЦІЯ

Мета роботи. Визначення актуальних напрямків імплементації в освітній процес питань організації та надання паліативної допомоги шляхом аналізу сучасного рівня знань і навичок у фрармацевтичних працівників у зазначеному сегменті охорони здоров'я.

Матеріали і методи. У дослідженні з визначення рівня теоретичних знань і практичних навичок із питань організації та надання паліативної допомоги хворим взяли участь 378 респондентів - фрармацевтичних працівників із сраховою освітою різного освітнього рівня. У роботі використано соціологічний метод дослідження, математичні та статистичні методи обробки даних. 3 метою наочного представлення результатів застосовано графрічні прийоми аналізу.

Результати й обговорення. За середнім показником результатів проведеного опитування фрармацевтичних орахівців із питань організації та надання паліативної допомоги, встановлено, що $67 \%$ анкетованих продемонстрували середній рівень поінсрормованості; 34 \% опитаних мали високий рівень знань; 21 \% опитаних - низький рівень знань, відповідно. Детальний аналіз відповідей респондентів дав змогу визначити, що фрармацевтичні фрахівці розуміють окремі аспекти паліативної допомоги. Респонденти продемонстрували належний рівень знань 3 питань основних потреб паліативних хворих і складових фрармацевтичних послуг при наданні паліативної допомоги. Також виявлено низку питань, в яких фрармацевтичним срахівцям бракує знань. Зокрема, знання положеннь основних законодавчих актів щодо регулювання обігу та застосування лікарських засобів у паліативній допомозі, переліку захворювань, які потребують надання паліативної допомоги. Залежності рівня знань респондентів щодо організації паліативної допомоги від набутого освітнього рівня фрармацевтичної освіти не встановлено.

Висновки. У статті обґрунтовано доцільність упровадження заходів освітньо-наукового спрямування з метою підвищення ефективності надання паліативної допомоги в Україні з урахуванням світових тенденцій розвитку охорони здоров'я та напрямків розвитку вітчизняної паліативної допомоги.
Вступ. Міжнародний досвід свідчить, що недостатній рівень необхідних знань з організації та упровадження паліативної допомоги (ПД) впливає на розвиток та якість її надання [1-5]. Провідні експер- ти ВООЗ рекомендують включити до освітніх програм підготовки фахівців галузі охорони здоров'я (О3) загальні положення $з$ паліативної допомоги та принципів лікування хронічного больового синдрому

ISSN 2312-0967. Фармацевтичний часопис. 2021. № 3 
як на до дипломному, так і на післядипломному рівнях. На сучасному етапі розвитку та соціалізації України також визначено пріоритетні напрямки, завдання і механізми реалізації державної політики в галузі освіти та О3. Зокрема, положення «Національної стратегії розвитку освіти на 2012-2021 рр.» та «Стратегії розвитку паліативної допомоги в Україні на період до 2025 р.», які встановлюють необхідність забезпечення відповідності національної системи освіти сучасним глобалізаційним процесам із метою розвитку держави та інтегрування національної системи освіти в європейський і світовий освітній простір [6-10].

3 огляду на зазначене, метою нашої роботи стало визначення актуальних напрямків імплементації в освітній процес питань організації та надання паліативної допомоги шляхом аналізу сучасного рівня знань та навичок у фрармацевтичних працівників у зазначеному сегменті О3.

Матеріали і методи. Дослідження проведено на базі Національного фрармацевтичного університету (НФаУ) за участю 378 респондентів, шляхом заповнення спеціально розроблених анкет. Термін проведення дослідження березень-червень 2018 р. та січень-квітень 2019 р. Основні блоки анкети складались зі вступної частини, а саме питань, що ілюструють соціально-демографічні характеристики респондента та основної частини (10 питань анкети, які спрямовані на дослідження поставленої мети). Умовою включення у дослідження була добровільна згода респондентів на участь в індивідуальному анонімному опитуванні.

Основні етапи дослідження складалися 3 фрормування статистичної гіпотези, визначення типу даних, вибору статистичного критерію, інтерпретації результатів та створення синтез-висновків стосовно вище перелічених етапів дослідження. Робоча гіпотеза дослідження ґрунтувалася на тому, що фрахівці з фрармацевтичною освітою мають на сьогодні недостатній рівень знань щодо принципів надання ПД, своєї ролі й функції у ПД у межах провадження своєї професійної діяльності. Первинна обробка анкетних даних ґрунтувалася на табулюванні, розрахунку багатовимірних розподілів ознак, класифрікації даних. Аналіз відповідей респондентів виконували із використанням номінальних шкал, підраховували частоту тих чи інших варіантів відповідей на поставлені питання. Результати розрахунків представлено у відносних та абсолютних показниках.

Аналіз рівня поінформованості фрармацевтичних працівників із питань ПД проведено за допомогою методу балів. Від загальної кількості балів максимальне значення становило 36 балів. За кожну позитивну відповідь було присвоєно один бал. При оцінці результатів дослідження рівня поінорормованості учасників анкетування оцінювали як високий, середній та низький. Критерієм віднесення до висо- кого рівня прийнято наявність від 25 до 36 позитивних відповідей на запитання анкети, за середній рівень прийнято від 13 до 24 відповідей, 12 і менше відповідно-низький рівень.

Порівняльний аналіз відповідей респондентів у групах проведено із використанням таблиць 3 напруженості. Вірогідність відмінностей показників (вибірки непов'язані) оцінювали за допомогою спрощеної фрормули t-критерію Стьюдента для відмінних розмірів вибірки.

Автоматизовану обробку отриманих даних здійснювали за допомогою програмного комплексу SPSS Statistica та Microsoft Excel.

Для визначення рівня поінформованості з питань ПД учасників опитування було розподілено на дві вибіркові групи:

І група - 208 осіб, або 55 \% опитаних, мали фрармацевтичну освіту;

II група - 170 осіб, або 45 \% опитаних, мали освітньо-кваліфрікаційний ступінь спеціаліст або магістр за спеціальністю «Фармація».

Результати розрахунку описових статистик I та II вибіркових груп наведено в таблиці 1.

Відповідно до чисельних показників асиметрії та ексцесу проведено оцінювання нормальності розподілу результатів відповідей у двох групах.

Число ступенів свободи $f=376$. Розраховане значення фрактичного критерію $\left(t_{p}=1,88\right)$ менше критичного значення $\left(t_{\kappa p}=1,88=1,96\right)$. Таким чином, можемо дійти висновку, що відмінності статистично не значущі (при рівні значущості $p=0,05)$, відповідно, певних відмінностей у рівні поінформованості з питань ПД між тими, хто здобуває і тими, хто має вищу фрармацевтичну освіту, не спостерігається.

За соціально-демографрічними характеристиками вибірка мала такі значення:

- середня фрармацевтична освіта - 208 осіб (55\%);

- вища орармацевтична освіта - 170 осіб (45 \%);

- досвід роботи у фрармацевтичному секторі 302 особи (80 \%), з них 274 (91 \%) особи - працівники аптек;

- $\quad$ за статтю: жінки - 321 особа (85 \%); чоловіки - 57 опитаних (15\%);

- $\quad$ середній вік респондентів - 22,7 року.

Результати й обговорення. Як свідчать результати дослідження більшості респондентів, а саме 291, що склало 77 \% опитаних, знайоме поняття «паліативна допомога». 3 них правильне визначення цього терміну надали 99 респондентів (34\%), близьке до правильного визначення надали 192 опитаних (66 \%). Разом із тим, для 87 осіб, що склало 23 \%, термін «паліативна допомога» виявився зовсім невідомим.

Результати відповідей респондентів на питання анкети представлено в таблиці 2.

ISSN 2312-0967. Pharmaceutical review. 2021. № 3 
Фармацевтична освіта Pharmaceutical education

\section{Таблиця 1}

Результати розрахунків описових статистик I та II вибіркових груп

\begin{tabular}{|c|c|c|}
\hline Описові статистики & I група & II група \\
\hline Середнє арифметичне & 17,03846154 & 22,38823529 \\
\hline Стандартна помилка & 0,396229333 & 0,381634442 \\
\hline Медіана & 17 & 24 \\
\hline Мода & 19 & 27 \\
\hline Стандартне відхилення & 5,714500713 & 4,975904349 \\
\hline Вибіркова дисперсія & 32,65551839 & 24,75962409 \\
\hline *Ексцес (фрактичне значення) & 0,736840506 & 0,28810106 \\
\hline *夫Асиметрія (фрактичне значення) & $-0,147058048$ & $-0,868945662$ \\
\hline Діапазон & 29 & 25 \\
\hline Мінімум & 3 & 8 \\
\hline Максимум & 32 & 33 \\
\hline Об'єм вибірки & 208 & 170 \\
\hline Рівень довіри (95,0 \%) & 0,781162324 & 0,753384723 \\
\hline Рівень значущості & 0,05 & 0,05 \\
\hline
\end{tabular}

Примітки: * - критичне значення ексцесу 0,82; ** - критичне значення асиметрії 0,3.

\section{Таблиця 2}

Результати аналізу відповідей респондентів щодо принципів організації та надання паліативної допомоги

\begin{tabular}{|c|c|c|c|}
\hline \multirow{2}{*}{ № 3/п } & \multirow{2}{*}{ Критерії оцінки } & \multicolumn{2}{|c|}{ Кількість } \\
& & \multicolumn{2}{|c|}{ респондентів } \\
\cline { 3 - 4 } & 2 & 3 & 4 \\
\hline 1 & 2 & 3 & 4 \\
\hline
\end{tabular}

Розподіл думок респондентів щодо визначення основних потреб паліативних пацієнтів:

\begin{tabular}{|c|l|r|c|}
\hline 1 & морально-психологічна підтримка & 339 & 94,4 \\
\hline 2 & симптоматичне лікування та знеболення & 271 & 75,5 \\
\hline 3 & фрармацевтична опіка & 271 & 75,5 \\
\hline 4 & просресійний догляд & 257 & 71,6 \\
\hline 5 & соціальна допомога & 242 & 67,4 \\
\hline 6 & духовний супровід & 155 & 43,2 \\
\hline 7 & юридичний супровід & 106 & 29,5 \\
\hline
\end{tabular}

Розподіл думок респондентів щодо визначення складових допомоги фрармацевтичних фрахівців у ПД:

\begin{tabular}{|c|c|c|c|}
\hline 8 & $\begin{array}{l}\text { знаходити, оцінювати та інтерпретувати інсрормацію про ЛЗ, які } \\
\text { використовують у ПД }\end{array}$ & 286 & 79,6 \\
\hline 9 & $\begin{array}{l}\text { розуміти, як підхід ПД поліпшить оцінку й лікування симптомів } \\
\text { захворювання }\end{array}$ & 208 & 58 \\
\hline 10 & $\begin{array}{l}\text { розуміти зміну потреб у фрармакологічній та фрармацевтичній допомозі } \\
\text { впродовж перебігу захворювання, яке обмежує термін життя }\end{array}$ & 203 & 56,5 \\
\hline 11 & інтегрувати принципи ПД у фрармацевтичну практику & 169 & 47 \\
\hline 12 & $\begin{array}{l}\text { надавати консультативні послуги іншим фрахівцям О3 щодо } \\
\text { спеціалізованих Л3 }\end{array}$ & 160 & 44,5 \\
\hline 13 & надавати індивідуальну фрармацевтичну допомогу паліативним хворим & 121 & 33,7 \\
\hline
\end{tabular}

Розподіл думок респондентів щодо визначення нозологічних груп захворювань, які супроводжуються паліативним станом:

\begin{tabular}{|l|l|l|l|}
\hline 14 & злоякісні новоутворення & 314 & 88,9 \\
\hline
\end{tabular}

ISSN 2312-0967. Фармацевтичний часопис. 2021. № 3 
Фармацевтична освіта Pharmaceutical education

Продовження табл. 2

\begin{tabular}{|c|c|c|c|}
\hline 1 & 2 & 3 & 4 \\
\hline 15 & ВІЛ/СНІД & 275 & 77,9 \\
\hline 16 & групи хвороб, які загрожують або обмежують тривалість життя & 275 & 77,9 \\
\hline 17 & уроджені аномалії розвитку центральної нервової системи & 202 & 57,2 \\
\hline 18 & церебральні паралічі та інші паралітичні синдроми & 198 & 56 \\
\hline 19 & $\begin{array}{l}\text { групи захворювань, які супроводжуються хронічним больовим } \\
\text { синдромом }\end{array}$ & 164 & 46,4 \\
\hline 20 & хромосомні аномалії & 154 & 43,6 \\
\hline 21 & інші уроджені аномалії & 145 & 41 \\
\hline 22 & $\begin{array}{l}\text { доброякісні новоутворення головного мозку та центральної нервової } \\
\text { системи }\end{array}$ & 120 & 34 \\
\hline 23 & родова травма (церебральний крововилив, церебральні порушення) & 101 & 28,6 \\
\hline \multicolumn{4}{|c|}{ Розподіл думок респондентів щодо визначення ЛЗ для симптоматичної фрармакотерапії у пД в Україні } \\
\hline 24 & морфін & 299 & 84,7 \\
\hline 25 & габапентин* & 227 & 64,3 \\
\hline 26 & налоксон* & 174 & 49,3 \\
\hline 27 & амітриптилін & 159 & 45 \\
\hline 28 & ондансетрон & 140 & 39,6 \\
\hline 29 & дексаметазон & 106 & 30 \\
\hline 30 & лактулоза & 53 & 15 \\
\hline \multicolumn{4}{|c|}{ Розподіл думок респондентів щодо визначення поняття «Паліативна допомога»: } \\
\hline 31 & правильне визначення & 99 & 26 \\
\hline 32 & близьке до правильного визначення & 192 & 51 \\
\hline 33 & невідоме & 87 & 23 \\
\hline
\end{tabular}
пд.

Примітка. * - станом на момент дослідження Л3 не включені до переліку Олз, які застосовують при наданні

Результати розподілу респондентів за рівнем поінфрормованості з питань ПД у групах наведено на рисунку 1.

Так, у І вибірковій групі найбільше анкетованих має середній рівень поінорормованості з питань ПД, що становило $72 \%$. Високий рівень продемонстрували $22 \%$ респондентів. Низький рівень спостерігають у $21 \%$ опитаних.

У II вибірковій групі також превалював середній рівень поінорормованості фрармацевтичних фрахівців із питань ПД, що складає 61 \%. Високий рівень спостерігали у $46 \%$ респондентів. Низький рівень мали $20 \%$ опитаних.

За середнім показником результатів проведеного опитування фрармацевтичних фрахівців з питань організації та надання ПД, встановлено:

- $\quad 67 \%$ анкетованих продемонстрували середній рівень поінформованості;

- $34 \%$ опитаних мали високий рівень;

- $21 \%$ опитаних показали низький рівень знань.
За оцінками фрахівців, організація та надання фрармацевтичної ПД повинна здійснюватися на засадах специфрічної професійної компетентності відповідно до принципів надання ПД [11-13]. При цьому, на думку опитуваних, найвагомішим завданням сучасної ПД є морально-психологічна підтримка, далі за значущістю виділяють симптоматичне лікування й знеболення та фрармацевтичну опіку, професійний догляд і соціальну допомогу (рис. 2).

щодо переліку нозологічних груп захворювань, які можуть супроводжуватися паліативним станом, респонденти відзначили злоякісні новоутворення; ВІЛ/СНІД та групи захворювань, які становлять загрозу життю або обмежують тривалість життя; уроджені аномалії розвитку ЦНС; церебральні паралічі та інші паралітичні синдроми; решту представлених у питанні захворювань відзначили менше 50 \% опитуваних (рис. 3). Даний фракт свідчить про наявність десріциту знань про контингенти населення, яким необхідна Пд.

У наступному питанні респондентам було запропоновано відзначити варіанти відповідей, які, на їх думку,

ISSN 2312-0967. Pharmaceutical review. 2021. № 3 
Фармацевтична освіта

Pharmaceutical education

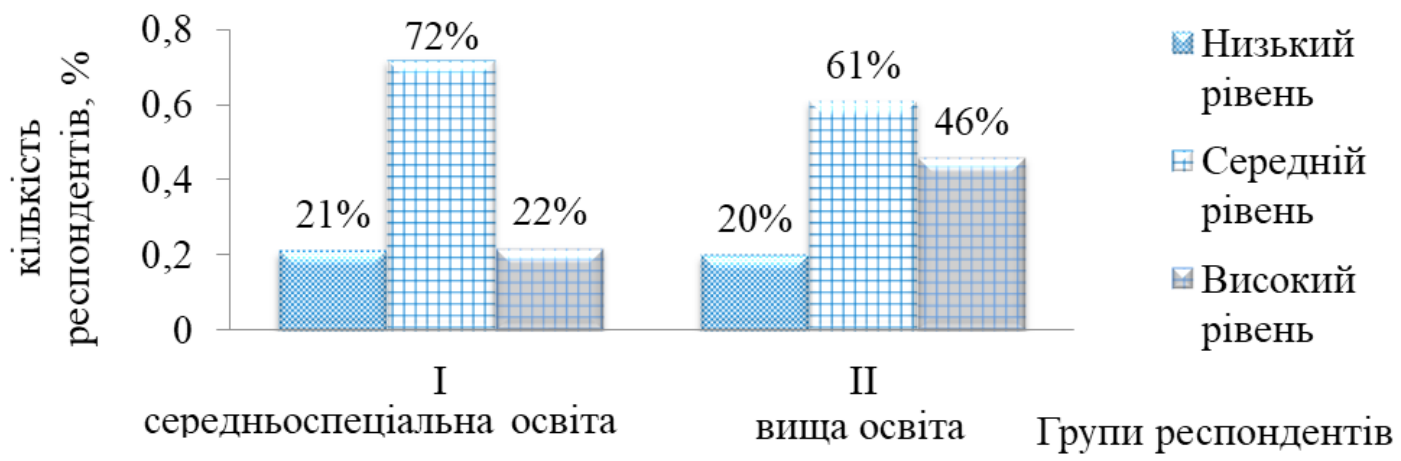

Рис. 1. Розподіл респондентів за рівнем поінформованості з питань паліативної допомоги (у вибіркових групах).

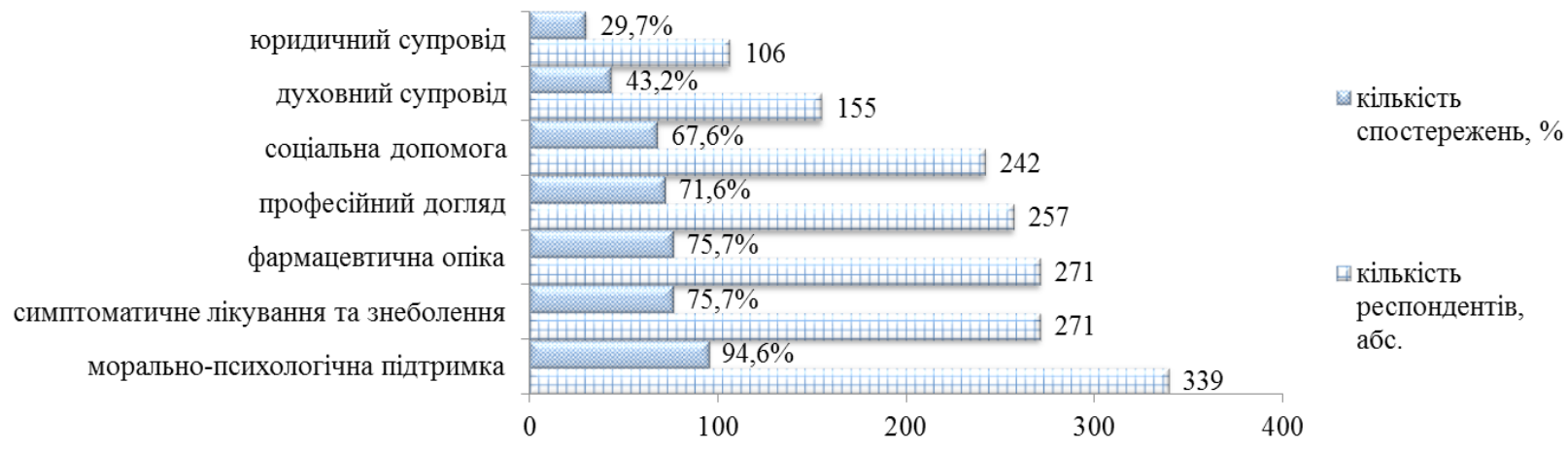

Рис. 2. Розподіл думок респондентів щодо визначення основних потреб паліативних пацієнтів.

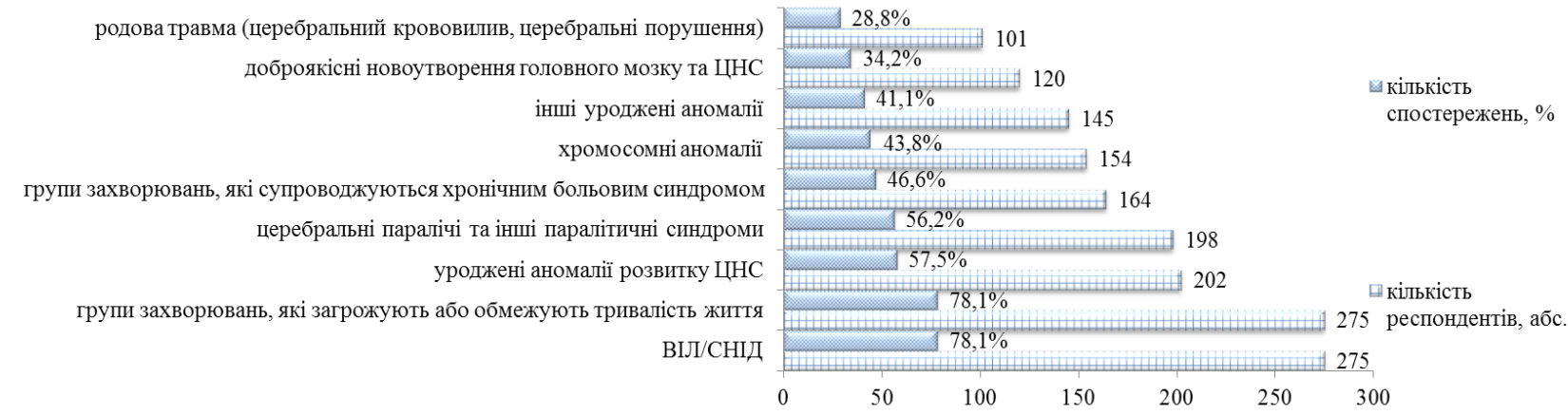

Рис. 3. Розподіл думок респондентів щодо визначення нозологічних груп захворювань, які супроводжуються паліативним станом.

відповідають основним завданням фрахівців ОЗ при наданні ПД за міжнародними стандартами. Відповідно пріоритетними заходами учасники анкетування вважали: розуміння значення основних потреб людей 3 обмеженими умовами життя та як вони можуть вплинути на потребу у фрармацевтичній допомозі; вміння застосовувати принципи ПД та пропонувати систему підтримки для забезпечення якомога кращої якості життя; забезпечення професійної допомоги пацієнтам із захворюваннями, які становлять загрозу життю 3 урахуванням індивідуальності кожної людини (рис. 4).

Необхідно відзначити, що респонденти погодились 3 твердженням, що як фрармацевтичні працівни- ки, впроваджуючи свою професійну діяльність, вони можуть застосовувати такі заходи: знаходити, оцінювати та інтерпретувати інорормацію про ЛЗ, які використовують при наданні ПД; розуміти, як підхід ПД може поліпшити оцінку і лікування симптомів; розуміти зміну потреб у фрармакологічній та фрармацевтичній допомозі людям впродовж перебігу захворювання, яке обмежує термін життя, інтегрувати принципи ПД у фрармацевтичну практику, надавати консультативні послуги іншим фрахівцям ОЗ щодо спеціалізованих ЛЗ (рис. 5).

Привертає увагу думка респондентів стосовно того, які знання про ПД доцільно отримувати у

ISSN 2312-0967. Фармацевтичний часопис. 2021. № 3 
розуміти та описувати значення терміна "умова, шо обмежує життя";

забезпечувати професійну допомогу пацієнтам із захворюваннями, які загрожують життю з урахуванням індивідуальності кожної людини;

розуміти й вміти застосовувати принципи Пд та пропонувати систему підтримки для забезпечення якомога крашої якості життя;

розуміти значення фізичних, соціальних, психологічних та духовних проблем людей з обмеженими умовами життя та як вони можуть вплинути на потребу в фармацевтичній допомозі;

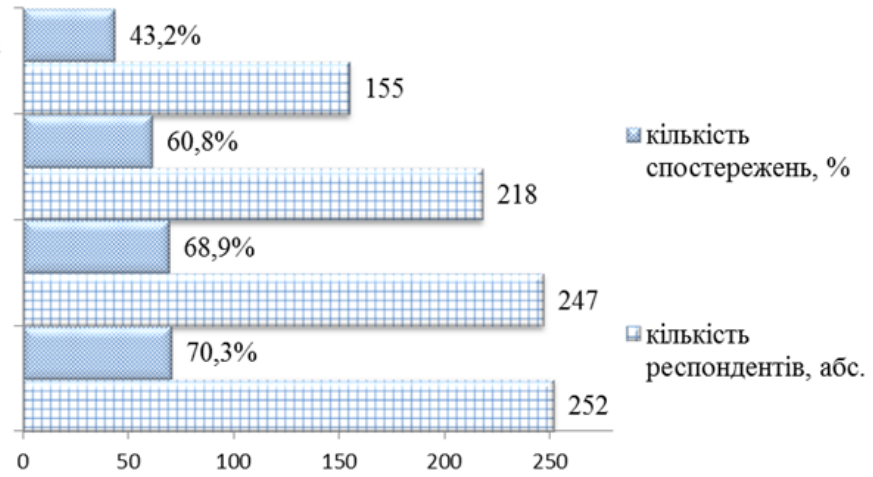

Рис. 4. Розподіл думок респондентів щодо визначення засад допомоги як фрахівців галузі охорони здоров'я.

надавати індивідуальну фармацевтичну допомогу людям з обмеженими умовами життя та сім'ям;

надавати консультативні послуги іншим фахівцям охорони здоров'я у відношенні спеціалізованих лікарських засобів;

інтегрувати принципи Пд у фармацевтичну практику;

розуміти зміну потреб у фармакологічній та фармацевтичній допомозі людям протягом перебігу захворювання, яке обмежує термін життя; розуміти,як підхід Пд поможе поліпшити оцінку й лікування симптомів захворювання;

знаходити, оцінювати та інтерпретувати інформацію про лікарські засоби, які використовуються при наданні Пд;

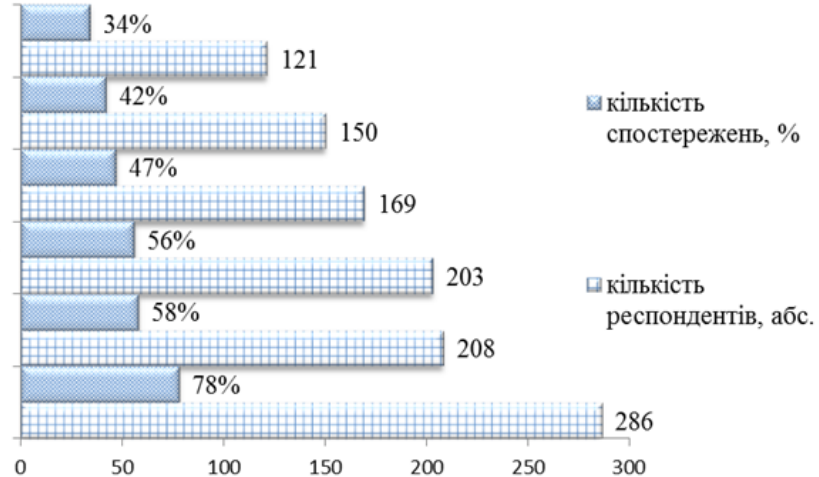

Рис. 5. Розподіл думок респондентів за визначенням складових допомоги фрармацевтичних працівників у паліативній допомозі.

рамках вищої фрармацевтичної освіти. Більшість опитуваних вказала на необхідне вивчення основних принципів й методів надання ПД та особливості фрармакотерапії в паліативних пацієнтів, менш ніж половина фахівців вважають вагомим вивчення нормативно-правової бази з ПД, органі- зацію ПД в Україні та проведення практичних за-

Результати проведеного опитування дали змогу отримати загальну картину рівня поінформованості фармацевтичних фрахівців з питань організації та надання ПД. У цілому, 22 \% опитаних показали високий нять (рис. 6).

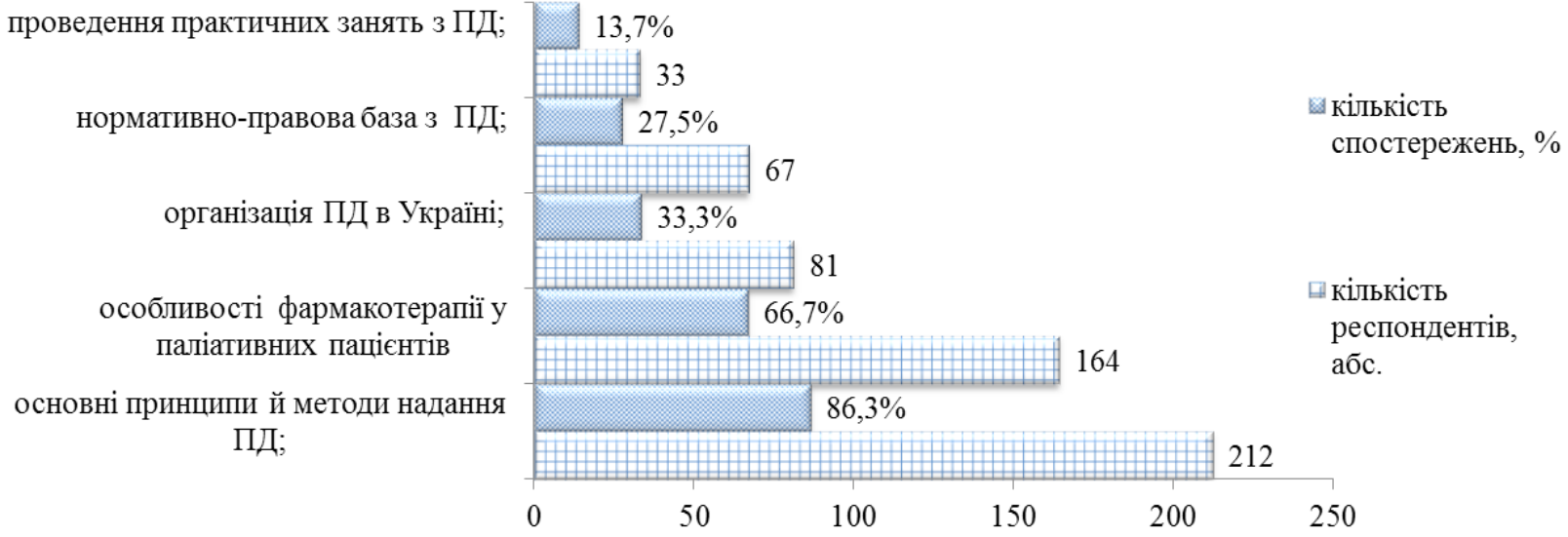

Рис. 6. Розподіл думок респондентів стосовно визначення сорери знань з паліативної допомоги, які доцільно отримувати в рамках вищої фрармацевтичної освіти.

ISSN 2312-0967. Pharmaceutical review. 2021. № 3 
Фармацевтична освіта

\section{Pharmaceutical education}

рівень поінформованості; 63 \% анкетованих показали середній рівень, $15 \%$ - низький рівень.

Найбільше анкетованих із середнім рівнем поінформованості припадає на групу фрармацевтичних працівників, які на момент опитування здобували вищу освіту (І група) - 69,8 \%. Високий рівень у даній групі припадає на 9,3 \% опитаних, низький рівень на 20,9\%.

У групі фрармацевтичних працівників з вищою освітою (II група) високий рівень поінформованості з ПД мають 37,1 \% опитаних, у 54,3 \% анкетованих знання на середньому рівні, у 8,6 \% - на низькому рівн (рис. 7).

Найбільшу частку опитаних із середнім рівнем поінфрормованості (61,1 \%) визначено в групі фрармацевтів. Частка респондентів із високим рівнем поінформованості в даній групі становила 11,1 \%, 3 низьким рівнем - 27,8 \%. У групі провізорів 46,7 \% опитаних було з високим рівнем поінформованості, 53,3\% - із середнім рівнем, низький рівень не спостерігали. У групі, що не працювали за фрахом на момент опиту- вання - 17,6 \% респондентів продемонстрували високий рівень поінформованості, 76,5 \% - відповідно середній рівень та 5,9 \% - низький (рис. 8).

Відповіді респондентів на питання «Як Ви вважаєте, на якому освітньому рівні у фрармацевтичних закладах освіти слід впроваджувати навчальні дисципліни з питань організації та надання Пд?» представлені на рисунку 9. Найбільший відсоток опитуваних вважали, що ці знання слід отримувати на першому (бакалаврському рівні), на це вказали майже 55 \% респондентів.

Стосовно результатів аналізу рівня поінформованості фрармацевтичних працівників, відповідно до визначених спеціальних профресійних компетентностей, ми встановили недостатній рівень теоретичних знань щодо особливостей надання ПД. Разом із тим, визначено відсутність практичних навичок в опитаних щодо надання ПД. Детальний аналіз відповідей респондентів дав змогу визначити, що у фрармацевтичних фрахівців $€$ розуміння окремих аспектів ПД. Наприклад, знання основних потреб паліативних

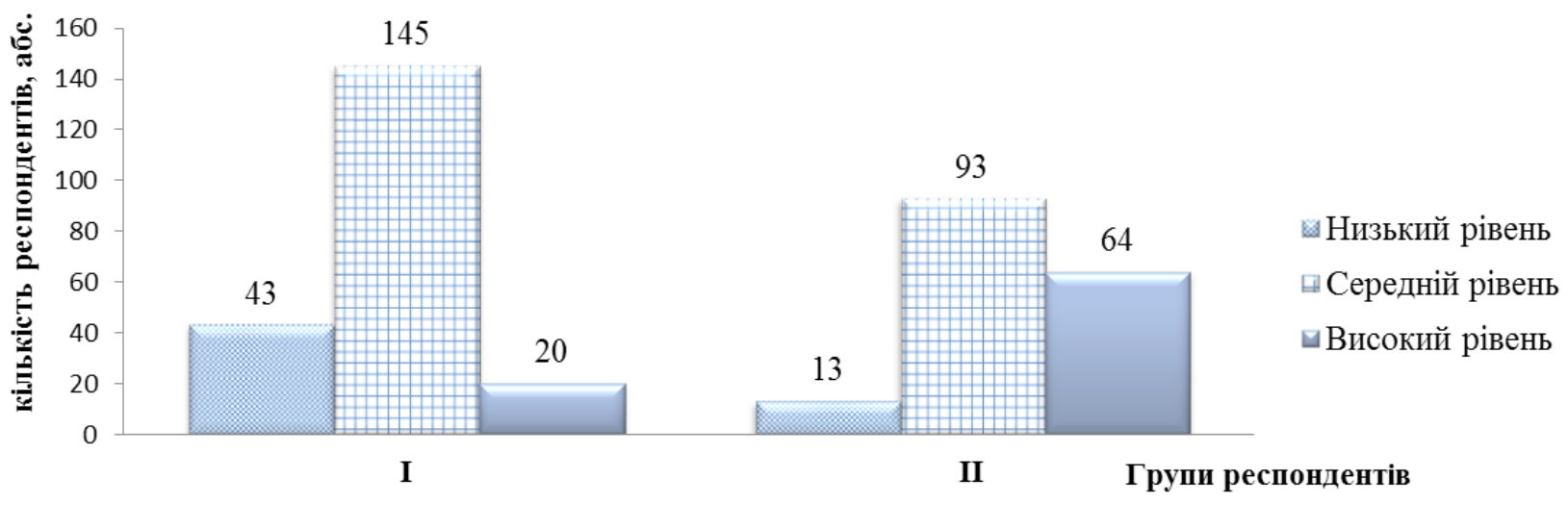

Рис. 7. Розподіл респондентів за рівнем поінформованості з питань паліативної допомоги (у групах).

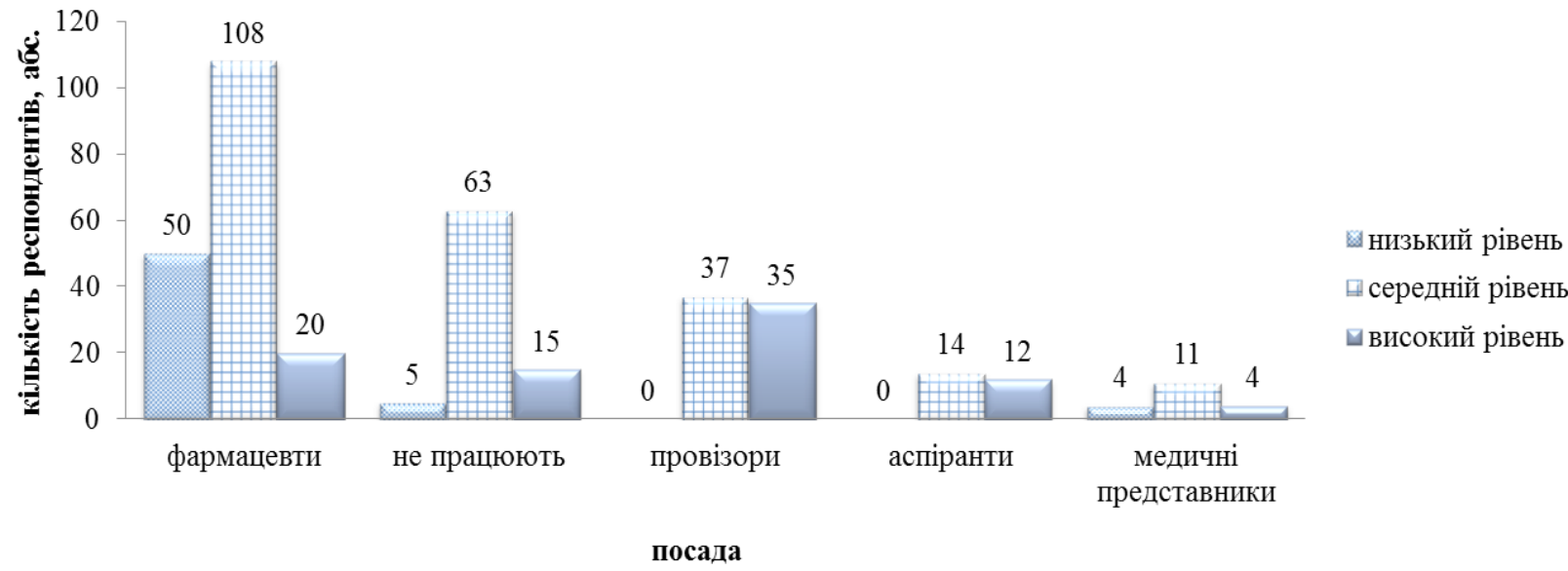

Рис. 8. Розподіл респондентів за рівнем поінорормованості з питань паліативної допомоги (за посадою).

ISSN 2312-0967. Фармацевтичний часопис. 2021. № 3 


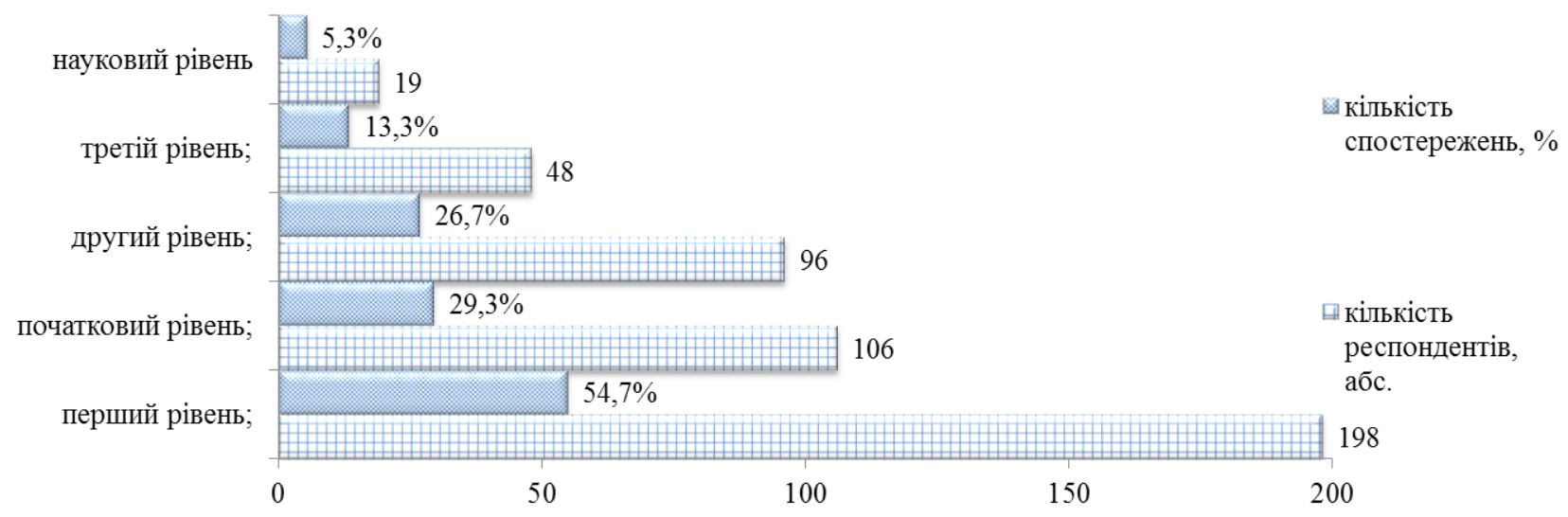

Рис. 9. Розподіл думок респондентів щодо визначення освітнього рівня для впроваджування навчальних дисциплін із паліативної допомоги.

хворих та складових фрармацевтичних послуг при наданні ПД. Також виявлено низку питань, стосовно яких фрармацевтичним фрахівцям бракує знань. Серед них перелік захворювань, які потребують надання ПД, положення основних законодавчих актів щодо регулювання обігу та застосування лЗ у ПД. Учасники дослідження акцентували увагу на необхідності вивчення основних принципів надання ПД та особливостей фрармакотерапії в паліативних пацієнтів, що, на нашу думку доцільно визначити як напрямок удосконалення змістової частини навчальних програм для майбутніх фрахівців фрармації.

Висновки. 1. За результатами дослідження думки фрармацевтичних орахівців $67 \%$ респондентів продемонстрували середній рівень знань щодо особливостей ПД. Визначено недостатній рівень теоретичних знань та практичних навичок 3 окремих питань ПД, до них належать: основні визначення, принципи та завдання ПД; нозологічні фрорми захво- рювань, при яких надають паліативні послуги; основні положення чинної нормативно-правової бази з організації ПД.

2. Аргументовано доцільність упровадження заходів освітньо-наукового спрямування 3 метою підвищення еорективності надання ПД в Україні, з урахуванням світових тенденцій розвитку ОЗ та напрямків розвитку вітчизняної ПД, зокрема:

- $\quad$ здійснення наукових досліджень у системі надання ПД із визначенням соціально-фрармацевтичної складової;

- розробка та удосконалення навчально-методичних кейсів 3 урахуванням особливостей організації та надання ПД на до- та післядипломному рівнях навчання для фрармацевтичних фрахівців.

Конфлікт інтересів: відсутній.

Conflicts of interest: authors have no conflict of interest to declare.

\section{EDUCATIONAL AND SCIENTIFIC ASPECTS OF PALLIATIVE CARE DEVELOPMENT IN UKRAINE}

\section{A. Kotvitska, I. V. Kubarieva, M. S. Beketova}

\section{National University of Pharmacy, Ministry of Health of Ukraine}

socpharm@nuph.edu.ua

The aim of the work. Determining the current areas of implementation in the educational process of the organization and provision of palliative care by analyzing the current level of knowledge and skills of pharmaceutical workers in this segment of health.

Materials and Methods. The study, aimed at determining the level of theoretical knowledge and practical skills in organizing and providing palliative care to patients, involved 378 respondents - pharmaceutical workers with professional education of different educational levels. The sociological research method, mathematical and statistical methods of data processing are used in the work. In order to visualize the results, graphical methods of analysis were used.

Results and Discussion. According to the average results of the survey of pharmaceutical specialists on the organization and provision of palliative care, it was found that $67 \%$ of respondents showed an average level of awareness; $34 \%$ of respondents had a high level of knowledge; $21 \%$ of respondents have a low level of knowledge, respectively. A detailed analysis of the respondents' answers allowed us to determine that pharmaceutical specialists have certain aspects of

ISSN 2312-0967. Pharmaceutical review. 2021. № 3 
palliative care. Respondents demonstrated an adequate level of knowledge in the basic needs of palliative care patients and components of pharmaceutical services in the provision of palliative care. There are also a number of issues in which pharmaceutical professionals lack knowledge. In particular, knowledge of the provisions of the main legislative acts on the regulation of the circulation and use of drugs in palliative care, the list of diseases that require palliative care, etc. The dependence of the level of knowledge of the respondents on the organization of palliative care on the acquired educational level of pharmaceutical education has not been established.

Conclusions. The article substantiates the expediency of introducing educational and scientific measures to increase the effectiveness of palliative care in Ukraine, taking into account global trends in health care and areas of domestic palliative care.

Key words: pharmaceutical workers; pharmaceutical education; palliative care.

\section{Список бібліографрічних посилань}

1. Підготовка студентів з питань надання паліативної допомоги населенню: міжнародний та національний досвід / В. М. Князевич та ін. Актуальні питання надання паліативної та хоспісної допомоги в Україні. Медико-юридичні та фрармацевтичні аспекти: матеріали II наук.-практ. конфр., М. Київ, 20-21 листоп. 2013 р. Київ : Талком, 2013. С. 22-32.

2. Медико-соціальна характеристика організації системи паліативної та хоспісної допомоги в Україні / Н. Г. Гойда та ін. Збірник. наук. праць співробіт. НМАПО імені П. Л. Шупика. 2014. № 23 (3). С. 101-115.

3. Громовик Б. П. Роль та завдання провізора у сорері паліативно-хоспісної медицини. Всеукраїнська науково-практична інтернет-конференція за участю міжнародних спеціалістів. Харків, 2013. 186 с.

4. Rémi C., Bausewein $C$. The role of the pharmacist in palliative care. 74th FIP World Congress of Pharmacy and Pharmaceutical Sciences. Bangkok, 2014. URL: https://www.fip.org/files/content/congresses-previous/ Bangkok_Thailand_World_Congress_of_Pharmacy_ and_Pharmaceutical_Sciences_2014.p̄pdf.

5. Кубарєва І. В., Бекетова М. С. Вивчення думки фахівців охорони здоров'я щодо ролі провізора у системі паліативної допомоги дітям. SCIENCE AND LIFE: proceedings of articles the international scientific conference. Czech Republic, Karlovy Vary - Ukraine, Kyiv, 16-17 November 2017. Czech Republic, Karlovy Vary: Skleněný Můstek, 2017. C. 181-185.

6. National Hospice and Palliative Care Organization (NHPCO). The hospice team. URL: https://www.nhpco.org/.

\section{References}

1. Kniazevych VM, Hubskyi Yul, Tsarenko AV, et al. [Training students in palliative care: international and national experience]. In: Voronenko YuV, Hubskyi Yul, editors. Materialy II naukovo-praktychnoi konferentsii Aktualni pytannia nadannia paliatyvnoi ta khospisnoi dopomohy $v$ Ukraini. Medyko-iurydychni ta farmatsevtychni aspekty; 2013 Lystopad 20-21; Kyiv. Kyiv: Talkom; 2013, p. 22-32.

2. Hoida NH, Hubskyi Yul, Kniazevych VM, et al. [Medical and social characteristics of the organization of the palliative and hospice care system in Ukraine]. Zbirnyk nauk. prats spivrobit. NMAPO imeni P. L. Shupyka.
7. Про Національну стратегію розвитку освіти в Україні на період до 2021року : Указ Президента України від 25.06.2013 р. № 344. URL: https://zakon.rada.gov.ua/ laws/show/344/2013\#Text.

8. Стратегія розвитку паліативної допомоги в Україні на період до 2027 р. URL: http://moz.gov.ua/article/ news/moz-proponue-kompleksnij-pidhid-schodo-organizacii-nadannja-jakisnoi-paliativnoi-dopomogi.

9. Вороненко Ю. В., Губський Ю. І., Царенко А. В. Створення системи паліативної і хоспісної допомоги в умовах ресрормування охорони здоров'я України: медичні та соціальні аспекти. Охорона здоров'я $i$ суспільство. 2014. № 1 (2). С. 63-75.

10. Core competencies in palliative care: an EAPC White Paper on palliative care education. Part 1. European Journal of Palliative Care. 2013. No. 20 (2). P. 86-91.

11. Громовик Б. П., Прокіп С. Є. Проблемні питання організації та фрармацевтичного забезпечення паліативно-хоспісної допомоги в Україні. Управління, економіка та забезпечення якості в фрармації. 2012. № 2 (22). C. 54

12. Retrospective analysis of pharmacist interventions in an ambulatory palliative care practice. J. D. Ma, V. Tran, C. Chan et al. Journal of Oncology Pharmacy Practice. 2016. Vol. 22 (6). P. 757-765. DOI: $10.1177 / 1078155215607089$.

13. Demler T. L. Pharmacist involvement in hospice and palliative care. US Pharmacist. 2016. Vol. 41 (3). P HS2-HS5.

2014;23(3): 101-15.

3. Hromovyk BP. [The role and tasks of a pharmacist in the field of palliative and hospice medicine]. Vseukrainska naukovo-praktychna internet-konferentsiia za uchastiu mizhnarodnykh spetsialistiv. Kharkiv; 2013. 186 p.

4. Rémi C, Bausewein $C$. The role of the pharmacist in palliative care. 74th FIP World Congress of Pharmacy and Pharmaceutical Sciences. Bangkok; 2014. Available from: https://www.fip.org/files/content/congresses-previous/Bangkok_Thailand_World_Congress_of_ Pharmacy_and_Pharmaceutical_Sciences_2014.pdf. 5. Kubarieva IV, Beketova MS. [Exploring the views of

ISSN 2312-0967. Фармацевтичний часопис. 2021. № 3 
health professionals on the role of the pharmacist in the system of palliative care for children]. In: Klimov IP, Ignatko IV, Mantusov VB, editors. Proceedings of articles the international scientific conference SCIENCE AND LIFE; 2017 November 16-17; Czech Republic, Karlovy Vary - Ukraine, Kyiv. Czech Republic, Karlovy Vary: Skleněný Můstek; 2017, p. 181-185.

6. National Hospice and Palliative Care Organization (NHPCO). The hospice team. Available from: https:// www.nhpco.org/.

7. Decree of the President of Ukraine of 2013 June 25 No. 344 "On the National Strategy for the Development of Education in Ukraine for the period up to 2021". Available from: https://zakon.rada.gov.ua/laws/ show/344/2013\#Text.

8. Strategy for the development of palliative care in Ukraine until 2027. Available from: http://moz.gov.ua/ article/news/moz-proponue-kompleksnij-pidhid-schodo-organizacii-nadannja-jakisnoi-paliativnoi-dopomogi.
9. Voronenko YuV, Hubskyi Yul, Tsarenko AV. [Creating a system of palliative and hospice care in the context of health care reform in Ukraine: medical and social aspects]. Okhorona zdorov'ia i suspilstvo. 2014;1(2): 63-75.

10. Core competencies in palliative care: an EAPC White Paper on palliative care education. Part 1. European Journal of Palliative Care. 2013;20(2): 86-91.

11. Hromovyk BP, Prokip SYe. [The problem questions of the organization and pharmaceutical provision of palliative-hospice care in Ukraine]. Upravlinnia, ekonomika ta zabezpechennia yakosti v farmatsii. 2012;2(22): 54

12. Ma JD, Tran V, Chan C, Mitchell WM, Atayee RS. Retrospective analysis of pharmacist interventions in an ambulatory palliative care practice. Journal of Oncology Pharmacy Practice. 2016;22(6): 757-65. DOI: $10.1177 / 1078155215607089$.

13. Demler TL. Pharmacist involvement in hospice and palliative care. US Pharmacist. 2016;41(3).

\section{Відомості про авторів}

Котвіцька А. А. - д. фрармац. наук, профресор, ректор, Національний фрармацевтичний університет Міністерства охорони здоров'я України, Харків, Україна. E-mail: socpharm@nuph.edu.ua., ORCID https://orcid.org/0000-0002-66501583.

Кубарєва І. В. - канд. фрармац. наук, доцент, доцент кафредри соціальної фрармації, Національний фрармацевтичний університет Міністерства охорони здоров'я України, Харків, Україна. E-mail: inna.kubarieva@gmail.com, ORCID https:// orcid.org/0000-0001-6617-2575.

Бекетова М. С. - аспірант, кафредра соціальної фрармації, Національний фрармацевтичний університет Міністерства охорони здоров'я України, Харків, Україна. E-mail: socpharm@nuph.edu.ua., ORCID https://orcid.org/0000-0002-29984192.

\section{Information about the authors}

Kotvitska A. A. - DSc (Pharmacy), Professor, rector, National University of Pharmacy of the Ministry of Health of Ukraine, Kharkiv, Ukraine, e-mail: socpharm@nuph.edu.ua, ORCID https://orcid.org/0000-0002-6650-1583.

Kubarieva I. V. - PhD (Pharmacy), Associate Professor, Associate Professor of the Department of Social Pharmacy, National University of Pharmacy of the Ministry of Health of Ukraine, Kharkiv, Ukraine, e-mail: inna.kubarieva@gmail.com, ORCID https://orcid.org/0000-0001-6617-2575.

Beketova M. S. - PhD-student, Department of Social Pharmacy, National University of Pharmacy Ministry of Health of Ukraine, Kharkiv, Ukraine. E-mail: socpharm@nuph.edu.ua., ORCID https://orcid.org/0000-0002-2998-4192. 